\title{
Ozone Therapy in Burns: our experience in Egypt [abstract]
}

\section{Khaled El_Tobgy}

General Surgeon, Diving \& hyperbaric medicine Consultant, Ozone Therapist Ex-Director of Naval Hyperbaric Medical Institute Egypt. Director of Lekhweya Diving, Hyperbaric and Ozone Therapy unit Qatar

\section{ABSTRACT}

\section{Oे OPEN ACCESS}

\section{Citation}

El_Tobgy K. Ozone Therapy in Burns: our experience in Egypt [abstract]. Proceedings of The World Conference on Ozone Therapy in Medicine, Dentistry and Veterinary. Ancona (Italy). September 22nd - 23rd - 24th , 2017. J Ozone Ther. 2019;3(4):12. doi 10.7203/jo3t.3.4.2019.15417

\section{Academic Editor \\ Jose Baeza-Noci, \\ School of Medicine, Valencia \\ University, SPAIN}

\section{Editor}

World Federation of Ozone Therapy, Bolgna, ITALY

\section{Received}

June 17, 2019

\section{Accepted}

December 08, 2019

Published

December 30, 2019

\section{Intellectual Property}

Khaled El_Tobgy.

This is an open access article distributed under the terms of the Creative Commons Attribution License (CC BY 4.0), which permits unrestricted use, distribution, and reproduction in any medium, provided the original author and source are credited.

\section{Author Information}

Email: drkeltobgy@gmail.com
Background: Burn injuries are one of the major health problems all over the world. The problem of infection in burn wounds is considered a major problem and the main cause of death in many burned patients. Ozone has been used with good results in the treatment of patients with diabetic foot, because of its germicidal properties and its influence on the processes of oxygen metabolism, and other effects.

Objective: We report the effect of Ozone therapy on the healing process of recent burns in the Burn unit of the Alexandria Main University Hospital and Plastic Surgery Department Faculty of Medicine, Alexandria University.

Patients and methods: A review of two RCTs of 140 patients with recent burns done to investigate the effects of topical application of ozonized water, ozone gas (Sauna or Bagging), and ozonized olive oil in the treatment of recent burns .

Results: All patients manifested clinical improvement by Topical Ozone Therapy. The healing time of the ozone treated wounds was significantly lower than that of the control wounds. The full-thickness infected necrotic wounds that were treated with ozone showed earlier clearance of necrotic tissue and infection than the control wounds and became ready for skin grafting in a significantly lower time than the control wounds. Histopathological studies revealed marked increase in the expression of the fibronectin and transforming growth factor-B after treatment in comparison to the control wounds

Conclusions: Topical application of ozone causes a highly significant reduction in the healing time of the recent burn injuries. 